\title{
Implementasi Nilai-nilai Pendidikan Multikultural di SMA Nasional 3 Bahasa Putera Harapan Purwokerto (Pu Hua School)
}

\author{
Tri Nurhani \\ Pascasarjana Manajemen Pendidikan Islam IAIN Purwokerto \\ trinurhani90@gmail.com
}

\begin{abstract}
The purpose of this study is to present how the implementation of multicultural education in Putera Harapan Purwokerto (Pu Hua School) National 3 High School. Where this school has a policy as a place that accommodates students from various backgrounds both ethnic, religious, racial, cultural, and linguistic. This multicultural, multireligion, and multilingual school is very interesting to be used as a model for applying multicultural education in educational institutions and by the plurality of Indonesian society. The results of this study indicate that: First, the implementation of multicultural education in Putera Harapan Purwokerto (Pu Hua School) 3 National High School has fulfilled the five dimensions of multicultural education concepts including content integration, construction knowledge, prejudice reduction, equity paedagogy, and empowering school culture and social culture. Second, in the agenda of activities compiled and implemented in the National High School 3 Language of Putera Harapan Purwokerto (Pu Hua School) contains multicultural education values consisting of the values of Democracy, Humanism values, and the value of Plularism. Third, In the application stage of multicultural education in the National High School 3 Languages Putera Harapan Purwokerto (Pu Hua School) is included in the implementation of the Transformation approach where at this level of students can have a point of view, see concepts, issues, themes, and problems from several perspectives and points of view ethnicity. They can compete, argue with each other, and start daring to see things from a different perspective.
\end{abstract}

Keywords: multicultural education, multicultural values, Putra Harapan

\begin{abstract}
Abstrak: Tujuan penelitian ini adalah untuk menyajikan tentang bagaimana implementasi pendidikan multikultural di SMA Nasional 3 Bahasa Putera Harapan Purwokerto (Pu Hua School). Di mana sekolah ini memiliki kebijakan sebagai wadah yang menampung peserta didik dari berbagai macam latar belakang baik secara suku, agama, ras, budaya dan bahasa. Sekolah dengan konsep multikultural, multi agama dan multi bahasa ini sangat menarik untuk dijadikan model penerapan pendidikan multikultural di lembaga pendidikan sesuai dengan keadaan masyarakat Indonesia yang plural. Hasil penelitian ini menunjukkan bahwa: Pertama, implementasi pendidikan multikultural di SMA Nasional 3 Bahasa Putera Harapan Purwokerto (Pu Hua School) telah memenuhi konsep lima dimensi pendidikan multikultural meliputi intregrasi konten, proses penyusunan pengetahuan, mengurangi prasangka, pedagogi kesetaraan, dan budaya sekolah dan struktur sekolah yang memberdayakan. Kedua, agenda kegiatan yang disusun dan dilaksanakan SMA Nasional 3 Bahasa Putera Harapan Purwokerto (Pu Hua School) mengandung nilai-nilai pendidikan multikultural
\end{abstract}


yang terdiri atas nilai demokrasi, nilai humanisme dan nilai plularisme. Ketiga, pada tahap penerapan pendidikan multikultural SMA Nasional 3 Bahasa Putera Harapan Purwokerto (Pu Hua School) termasuk dalam implementasi pendekatan Transformasi di mana pada jenjang ini siswa sudah mampu memiliki sudut pandang, melihat konsep, isu, tema, dan problem dari beberapa perspektif dan sudut pandang etnis. Siswa dapat berkompetisi, beradu argumentasi, dan mulai berani melihat sesuatu dari perspektif yang berbeda.

Kata kunci: pendidikan multikultural, nilai-nilai multicultural, Putra Harapan

\section{A. Pendahuluan}

Bangsa Indonesia didirikan dengan dengan darah dan air mata mereka yang rela mengorbankan jiwanya atas nama cinta pada negerinya tanpa memandang apa suku, agama, ras, warna kulit, bahasa, tradisi, dan sebagainya. Ini menjadi pekerjaan rumah penting yang harus segera diatasi dan wajib melakukan pencegahan terhadap pelanggaran-pelanggaran yang terjadi. Pendidikan di Indonesia menjadi kunci utama dalam pembentukan karakter bangsa menjunjung tinggi nilai budaya toleransi dan nasionalisme. Agar Bhineka Tunggal Ika tidak hanya menjadi semboyan belaka tanpa menjadi karakter pada jiwa.

David Wijaya mengungkapkan salah satu problematika bangsa Indonesia dewasa ini yaitu memudarnya kesadaran terhadap nilai-nilai budaya bangsa. ${ }^{1}$ Pembangunan dalam bidang budaya mengalami kemajuan yang ditandai oleh meningkatnya pemahaman terhadap keberagaman nilai budaya bangsa. Permasalahan lainnya menurut David ${ }^{2}$ yakni tentang ancaman disintegrasi bangsa. Ancaman dan gangguan dalam kedaulatan negara, keselamatan bangsa, dan keutuhan wilayah sangat berkaitan dengan posisi geografis Indonesia, kekayaan alam yang melimpah, belum tuntasnya pembangunan budaya dan karakter bangsa, terutama pemahaman terhadap multikulturalisme yang berdampak terhadap munculnya gerakan separatis dan konflik horizontal.

Berdasarkan informasi dari situs Kompas pada hari Selasa, 9 Januari 2018 dengan konten kasus intoleransi yang masih sering terjadi di Jawa Tengah selama tahun 2017. Hasil penelitian tentang kebebasan beragama oleh Lembaga Studi Sosial dan Agama (elSA) Semarang menyebutkan setidaknya terdapat puluhan kasus pelanggaran terjadi sepanjang tahun 2017 lalu. Kali ini, mayoritas pelanggaran didominasi penolakan terhadap kegiatan berbasis agama. Menurut koordinator advokasi elSA Semarang, Ceprudin mengatakan bahwa pelanggaran intoleransi masih didominasi kasus terorisme, kasus penolakan dan penghentian rumah ibadah, pembubaran kegiatan keagamaan. Masalah intoleransi sendiri hampir setiap tahun masih berkutat pada pendirian rumah ibadah, dan konflik horizontal di kalangan masyarakat. Permasalahan intoleransi di 2017 pada dasarnya tak jauh berbeda persoalan tahun sebelumnya. Persoalan penolakan tempat ibadah juga masih menjadi catatan serius. Pada 2017, kasus itu masih terjadi di sejumlah tempat di Jawa Tengah.

Dalam penelitiannya, penolakan rumah ibadah sepanjang 2017 yaitu penolakan Kapel di Sukoharjo, Masjid Arqom di kota Pekalongan, penolakan GKI Mojosongo Jebres, Solo

${ }^{1}$ David Wijaya, Pendidikan Budaya dan Karakter Bangsa Untuk Sekolah dan Perguruan Tinggi (Jakarta: Mitra Wacana Media, 2017), h. 23.

${ }^{2}$ David Wijaya, h. 24 
dan Gereja Pantekosta Colomadu Karanganyar. Penolakan lain yang terjadi yaitu yang menimpa GKJ Tanjung Brebes, Gereja Injil di GITJ di Jepara, Gldl di Solo, GKJ Mejasem, Masjid Ahmadiah Kendal, Mushala Ahmadiah Boyolali, dan perusakan sanggar Sapta Darma Rembang. Adapun penolakan kegiatan berbasis agama terjadi di sejumlah wilayah antara lain penolakan kegiatan bedah buku di IAIN Solo, diskusi dharma talk show di Sukoharjo, pengajian Assyura, perayaan Cap Gomeh, pork festival, pembubaran acara HTI, pelarangan kegiatan Felik Siaw, penolakan Gus Nur, deklarasi FPI di Semarang, pembubaran kegiatan dangdutan, valentine day, hajatan HUT RI, dan penolakan aksi 1000 lilin.

Direktur elSA Semarang, Tedi Kholiludin ${ }^{3}$ mengatakan, persoalan perusakan tempat menunjukkan tren negatif kebebasan berekspresi. Semestinya masyarakat bisa lebih terbuka untuk menerima perbedaan. Menerima perbedaan inilah yang disebut sebagai toleransi beragama. Toleransi menjadi kebajikan jika dipahami dengan upaya saling pengertian dan kerja sama memberikan jalan bagi masyarakat untuk menengahi konflik secara damai.

Dari data tersebut, dapat disimpulkan bahwa hingga kini Indonesia masih rawan isu intoleransi. Penolakan terhadap kebhinekaan membuat negeri ini tidak maju-maju, malah cenderung mengalami kemunduran. Kita mudah terpecah dan terprovokasi dengan isu SARA. Contohnya jika ada calon pemimpin dari kaum minoritas, sejumlah komunitas/organisasi masyarakat langsung melakukan provokasi berujung demonstrasi.

Indonesia adalah negara yang kaya akan budaya, budaya perbedaan yang besar yang memiliki berjuta suku ras dan etnis maka bangsa ini harus saling mengenal dalam artian yang lebih dalam harus saling mengerti perbedaan, menghargai dengan kesetaraan seperti diterangkan dalam QS.al-Hujurat/49:13 yang berbunyi: ${ }^{4}$

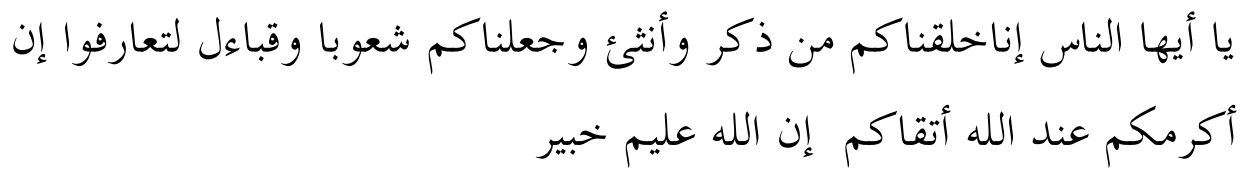

Hai manusia sesungguhnya Kami menciptakan kamu dari seorang laki-laki dan seorang perempuan dan menjadikan kamu berbangsa-bangsa dan bersuku-suku supaya kamu saling mengenal. Sesungguhnya orang yang paling mulia di antara di sisi Allah adalah orang yang paling bertaqwa di antara kamu. Sesungguhnya Allah Maha Mengetahui lagi Maha Mengenal (QS.al-Hujurat/49:13).

Bangsa Indonesia adalah bangsa yang besar dengan etnis dan ras juga suku yang bermacam-macam. Inilah kekayaan budaya Indonesia di tengah derasnya arus globalisasi. Namun hal ini bukan berarti tanpa masalah, identitas bangsa Indonesia dengan berbagai

${ }^{3}$ Dikutip dari Kompas, Penelitian: Kasus Intoleransi Masih Sering Terjadi di Jateng Selama 2017 dalam https://amp.kompas.com/regional/read/2018/01/09/13593181/penelitian-kasus-intoleransi-di-jatengselama-2017, diakses pada pukul 23.00 WIB 26 Desember 2018.

${ }^{4}$ al Quran al Karim, Departemen Agama RI, al Quran dan Terjemahannya: 1-30. (Jakarta: PT. Kumudasmoro Grafindo Semarang, 1994). 
macam kebudayaan di dalamnya memerlukam penyatu yang bukan berarti menghancurkan yang lain dan mengunggulkan kebudayaan tertentu. Pendidikan menjadi aset besar negara dalam proses pembentukan manusia Indonesia, manusia yang menunjukan ke-Indonesiaannya, mampu bertahan dan unggul serta mampu bersaing dengan bangsa-bangsa lain di dunia. Pendidikan haruslah terkonsep dengan baik dan matang melalui kurikulum yang mampu menjembatani kekayaan budaya Indonesia yang begitu beraneka ragam.

Tantangan terberat dalam pendidikan di negara tercinta ini sebagaimana dikatakan oleh Zamroni $^{5}$ adalah bagaimana pendidikan mampu menanamkan kesadaran akan pentingnya persatuan dan kesatuan bangsa pada diri peserta didik, sekaligus tantangan bagaimana pendidikan mampu mengembangkan kesadaran tersebut kepada peserta didik agar mampu menghargai berbagai realitas kebhinekaan dalam kehidupan bermasyarakat, berbangsa, dan bernegara. Tantangan ini harus mampu dijawab pendidikan guna mewujudkan masyarakat Indonesia yang berkeadaban dan demokratis sebagaimana cita-cita pendiri bangsa yang tertuang dalam Pancasila. Perlu adanya pemikiran mendalam bagaimana pendidikan mampu menanamkan prinsip-prinsip Multikulturalisme dalam berbagai tatanan dan sistem sekolah. Pemerintah, masyarakat, ahli, maupun praktisi pendidikan serta berbagai pihak yang terkait perlu kiranya memikirkan format bagaimana pendidikan yang diterapkan dapat menanamkan jiwa kebhinekaan. Pencarian format ini menjadi penting untuk dilakukan karena peserta didik adalah asset masa depan, dan sekolah merupakan sarana yang efektif untuk bagaimana menciptakan masyarakat masa depan.

Sekolah harus menjadi ujung tombak penyelenggaraan pendidikan multikultural. SMA Nasional 3 Bahasa Putera Harapan Purwokerto (Pu Hua School) merupakan sekolah yang memiliki keunikan tersendiri yaitu sekolah dengan peserta didik dan tenaga kependidikan memiliki latar belakang agama, ras, dan budaya yang berbeda. Bukan hanya itu, tetapi sekolah ini juga menerapkan 3 bahasa berbeda untuk pengembangan dan pembiasaan komunikasi sehari-hari yaitu bahasa Indonesia, bahasa Inggris, dan bahasa Mandarin. Tidak heran sekolah ini mendapat nilai akreditasi A, artinya sekolah ini memiliki mutu dan kualitas pendidikan yang patut diperhitungkan.

Berdasarkan wawancara dengan Dra. Sri Supriyanti, M.Pd. selaku kepala SMA Nasional 3 Bahasa Putera Harapan (Pu Hua School) merupakan sekolah dengan konsep multikultural di mana sekolah ini berdiri di bawah Yayasan Putera Harapan Purwokerto. Pada awalnya sekolah ini merupakan sekolah dengan peserta didik yang berasal dari etnis Tiong Hoa yang menduduki kota Purwokerto. Namun seiring berjalannya waktu kemudian sekolah ini berkembang menerima peserta didik dengan berbagai latar belakang agama, etnis, dan budaya. Sejak pertama berdiri Pu Hua memang sekolah yang mengutamakan penerapan tiga bahasa dalam pembelajaran sehari-hari yaitu bahasa Indonesia sebagai utama, dan bahasa Inggris dan Mandarin sebagai bahasa yang kedua. Proses pembelajaran siswa di sekolah dalam rangka pembentukan kepribadian dan mental supaya menjadi pribadi yang baik, lembut, dan berbudi luhur. Sekolah ini memiliki motto "rajin, trampil, tulus, bersahaja, tekun", untuk mewujudkan sekolah yang dikenal masyarakat luas dan mampu menghasilkan

${ }^{5}$ Zamroni, The Implementation of Multicultural Education. (Yogyakarta: Graduate Program the State University of Yogyakarta: Tiara Wacana Yogya, 2010). 
peserta didik yang berkualitas. $^{6}$

Seakan menjawab masalah yang dewasa ini mulai mengikis persatuan bangsa Indonesia yang sering terancam terkoyak karena kejamnya provokasi dan hilangnya nilainilai Binekha Tunggal Ika karena masalah-masalah yang berkaitan dengan isu sosial, budaya, dan politik. Sekolah ini hadir di tengah-tengah masyarakat menawarkan solusi agar dapat menjadi contoh bagaimana konsep pendidikan multikultural dijalankan secara nyata sebagaimana mestinya. Hal ini sangat menarik bagi peneliti, untuk mengetahui bagaimana pendidikan multikultural yang ada di SMA Nasional 3 Bahasa Putera Harapan Purwokerto (Pu Hua School) meliputi dalam hal implementasi dan agenda kegiatan yang menunjang program pendidikan multikultural di sekolah tersebut. Oleh karena itu peneliti mengajukan tesis dengan judul, Manajemen Pendidikan Sekolah Berbasis Multikultural di SMA Nasional 3 Bahasa Putera Harapan Purwokerto (Pu Hua School).

Berdasarkan uraian latar belakang masalah di atas, permasalahan yang akan diangkat dalam penelitian adalah bagaimanakah implementasi pendidikan multikultural di SMA Nasional 3 Bahasa Putera Harapan Purwokerto (Pu Hua School) dan apa saja agenda kegiatan yang dirancang dalam upaya mendukung program pendidikan multikultural di sekolah tersebut. Adapun penelitian ini memiliki tujuan untuk menganalisis implementasi pendidikan multikultural di SMA Nasional 3 Bahasa Putera Harapan Purwokerto (Pu Hua School). Serta menelaah agenda kegiatan dalam upaya mendukung program pendidikan multicultural di sekolah tersebut. Secara praktis, dalam penelitian diharapkan dapat bermanfaat dan diterima sebagai kontribusi dalam pengembangan pendidikan khususnya bagi sekolah yang ingin mengimplementasikan dan mengembangkan pendidikan multicultural. dan secara teoritis, penelitian ini diharapkan dapat bermanfaat bagi pengembangan keilmuan kajian terhadap pendidikan multikultural.

\section{B. Teori Dasar Pendidikan Multikultural}

Pendidikan multikultural sebagai wacana baru, pengertian pendidikan multikultural sesungguhnya hingga saat ini belum begitu jelas dan masih banyak pakar pendidikan yang memperdebatkannya. Namun demikian bukan berarti bahwa definisi pendidikan multikultural tidak ada atau tidak jelas. Sebetulnya sama dengan definisi pendidikan yang penuh penafsiran antara satu pakar dengan pakar yang lainnya di dalam menguraikan makna pendidikan itu sendiri. Hal ini juga terjadi pada penafsiran tentang arti pendidikan multikultural. ${ }^{7}$ Pendidikan multikultural merupakan wacana lintas batas. Dalam pendidikan multikultural terkait masalah-masalah keadilan sosial, demokrasi, dan hak asasi manusia. Tidak mengherankan apabila pendidikan multikultural berkaitan dengan isu-isu politik, sosial, kultural, moral, edukasional, dan agama. Tanpa kajian bidang-bidang ini maka sulit untuk diperoleh suatu pengertian mengenai pendidikan multikultural. ${ }^{8}$

${ }^{6}$ Hasil wawancara penulis dengan kepala SMA Nasional 3 Bahasa Putera Harapan Purwokerto, Dra. Sri Supriyanti, M.Pd. pada hari Kamis, 22 November 2018.

${ }^{7}$ Choirul Mafud, Pendidikan Multikultural (Yogyakarta: Pustaka Pelajar, 2008), h. 175.

${ }^{8}$ H.A.R. Tilaar, Jimmy dan Lody, Pedagogik Kritis, (Jakarta : Rineka Cipta, 2011),207. 
Dalam kajian penelitian ini penulis menggunakan teori yang dicetuskan oleh James. A. Banks mengenai pendidikan multikultural. Salah seorang ahli pendidikan multikultural di Amerika Serikat. Menurutnya dalam Kurniawati, pendidikan multikultural bermula dari ide bahwa semua murid, apapun latar belakang jenis kelamin, etnis, ras, budaya, kelas, sosial, agama, atau perkecualiannya, harus mengalami kesederajatan pendidikan di sekolahsekolah. ${ }^{9}$ Banks menjelaskan bahwa pendidikan multikultural adalah cara memandang realitas dan cara berpikir dan bukan hanya konten tentang beragam etnis, ras dan budaya. Secara spesifik.

Banks menyatakan bahwa pendidikan dapat dikonsepsikan atas lima dimensi, yaitu ${ }^{10}$ pertama, integrasi konten (content integration), pemaduan konten menangani sejauh mana guru menggunakan contoh dan konten dari beragam budaya dan kelompok untuk menggambarkan konsep, prinsip, generalisasi serta teori utama dalam bidang mata pelajaran atau disiplin ilmu. Proses penyusunan pengetahuan (construction knowledge), sesuatu yang berhubungan dengan sejauh mana guru membantu siswa paham, menyelidiki, dan untuk menentukan bagaimana asumsi budaya yang tersirat, kerangka acuan, perspektif dan prasangka di dalam disiplin mempengaruhi cara pengetahuan disusun di dalamnya. Kedua, mengurangi prasangka (prejudice reduction), dimensi ini fokus pada karakteristik dari sikap rasial siswa dan bagamaimana sikap tersebut dapat diubah dengan metode dan materi pengajaran. Ketiga, pedagogi kesetaraan (equity paedagogy), pedagogi kesetaraan ada ketika guru mengubah pengajaran mereka ke cara yang memfasilitasi prestasi akademis dari siswa dari berbagai kelompok ras, budaya, dan kelas sosial. termasuk gaya mengajar yang konsisten dengan banyaknya gaya belajar di dalam berbagai kelompok budaya dan ras. Keempat, budaya sekolah dan struktur sekolah yang memberdayakan (empowering school culture and social culture), praktik pengelompokan dan penanaman partisipasi olah raga, prestasi yang tidak proporsional, dan interaksi staf, dan siswa antar etnis dan ras adalah beberapa dari komponen budaya sekolah yang harus diteliti untuk menciptakan budaya sekolah yang memberdayakan siswa dari beragam kelompok, ras, etnis, dan budaya.

Untuk itu, para guru yang memberikan pendidikan multikultural harus memiliki keyakinan bahwa, perbedaan budaya memiliki kekuatan dan nilai, sekolah harus menjadi teladan untuk ekspresi hak-hak manusia dan penghargaan untuk perbedaan budaya dan kelompok, keadilan, dan kesetaraan kurikulum, sekolah dapat menyediakan pengetahuan, keterampilan, dan karakter (yaitu nilai, sikap, dan berbagai latar belakang, sekolah bersama, keluarga dan komunitas dapat menciptakan lingkungan yang mendukung multikultural. ${ }^{11}$

Sementara itu Yaya Suryana dan Rusiana menuliskan beberapa definisi dari para ahli. Pendapat itu akan peneliti sajikan sebagai berikut: ${ }^{12}$ Pertama Andersen dan Cusher menyatakan bahwa pendidikan multikultural dapat diartikan sebagai pendidikan mengenai keberagaman budaya. Kedua, James Banks mendefinisikan pendidikan multikultural merupakan suatu rangkaian kepercayaan dan penjelasan yang mengakui dan menilai

\footnotetext{
${ }^{9}$ Kurniawati Maryam, Pendidikan Kristiani Multikultural (Tangerang: Bamboo Bridge Press, 2014), h. 99.

10 James. A. Banks, an Introduction to Multicultural Education (Boston-London: Allyn and Bacon Press, 2002), p. 14.
}

12 Yaya dan Rusdiana, Pendidikan Multikultural (Bandung: Pustaka Setia, 2015), h. 196-197. 
pentingnya keberagaman budaya, dan etnis dalam bentuk gaya hidup, pengalaman sosial, identitas pribadi, kesempatan pendidikan dari individu, kelompok ataupun negara. Azra, menjelaskan pendidikan multikultural sebagai pengganti dari pendidikan interkultural, diharapkan dapat menumbuhkan sikap peduli dan mau mengerti atau adanya politik pengakuan terhadap kebudayaan kelompok manusia, seperti toleransi, perbedaan etnokultural dan agama, diskriminasi, HAM, demokrasi dan pluralitas, kemanusiaan universal, serta subjek-subjek lain yang relevan.

Begitu banyak definisi yang dikemukakan para ahli, pada hakikatnya memiliki satu benang merah bahwa pendidikan multikultural adalah sebuah model pendidikan yang memberikan kesempatan belajar yang sama pada semua peserta didik tanpa memandang apapun agama, jenis kulit, etnis, ras, budaya dan darimana dia berasal. Semua itu tidak boleh menghambat pembelajaran sehingga cita-cita dan tujuan pendidikan nasional dapat tercapai.

\section{Nilai-Nilai Pendidikan Multikultural}

Menurut Farida Hanum dalam Yaya Suryana ${ }^{13}$ nilai-nilai intinya dari pendidikan multikultural berupa demokratis, humanism, dan pluralism. Nilai demokratisasi atau keadilan merupakan sebuah istilah yang menyeluruh dalam segala bentuk, baik keadilan budaya, politik, maupun sosial. Keadilan merupakan bentuk bahwa setiap insan mendapatkan sesuatu yang dibutuhkan, bukan yang diinginkan. Nilai humanisme atau kemanusiaan manusia pada dasarnya adalah pengakuan akan pluralitas, heterogenitas, dan keragaman manusia. Keragaman itu dapat berupa ideologi, agama, paradigma, suku bangsa, pola pikir, kebutuhan, tingkat ekonomi, dan sebagainya. Nilai pluralisme bangsa adalah pandangan yang mengakui adanya keragaman dalam suatu bangsa, seperti yang ada di Indonesia. Istilah plural mengandung arti berjenis-jenis, tetapi pluralism bukan berarti sekadar pengakuan terhadap hal tersebut, melainkan memiliki implikasi-implikasi politis, sosial, dan ekonomi. Oleh sebab itu, pluralisme berkaitan dengan prinsip-prinsip demokrasi. Banyak negara yang menyatakan dirinya sebagai negara yang demokrasi, tetapi tidak mengakui adanya pluralisme dalam kehidupannya sehingga terjadi berbagai jenis segresi. Pluralisme berkenaan dengan hak hidup kelompok-kelompok masyarakat yang ada dalam suatu komunitas.

Adapun tujuan pendidikan multikultural, menurut Nurul Zuriah ${ }^{14}$ dapat dilihat dalam tiga aspek. Yang pertama tujuan pendidikan multikultural yang berkaitan dengan aspek sikap (attitudinal goals) adalah untuk mengembangkan kesadaran dan kepekaan kultural, toleransi kultural, penghargaan terhadap identitas kultural, sikap responsif terhadap budaya, keterampilan untuk menghindari dan meresolusi konflik. Kedua, tujuan pendidikan multikultural yang berkaitan dengan aspek pengetahuan (cognitive goals) adalah untuk memperoleh pengetahuan tentang bahasa dan budaya orang lain, dan kemampuan untuk menganalisis dan menerjemahkan perilaku kultural dan pengetahuan tentang kesadaran persepektif kultural. Dan yang terakhir, yaitu tujuan pendidikan multikultural yang

${ }^{13}$ Yaya dan Rusdiana, h. 200-201.

14 Nurul Zuriah, "Model Pengembangan Pendidikan Kewarganegaraan Multikultural Berbasis Kearifan Lokal dalam Fenomena Sosial Pasca Reformasi di Perguruan Tinggi”, Jurnal Penelitian UPI vol. 12 No. 2 Oktober 2011. 
berkaitan dengan pembelajaran (instruction goals) adalah untuk memperbaiki distorsi, stereotipe, dan kesalahpahaman tentang kelompok etnik dalam buku teks dan media pembelajaran; memberikan berbagai strategi untuk mengarahkan perbedaan di depan orang, memberikan alat-alat konseptual untuk komunikasi antar budaya; mengembangkan keterampilan interpersonal; memberikan teknik-teknik evaluasi; membantu klarifikasi nilai; dan menjelaskan dinamika kultural.

Berdasarkan uraian yang disampaikan oleh para pakar dan ahli mengenai pendidikan multikultural dapat dirumuskan tujuan pendidikan yang berbasis multikultural, yaitu untuk menanamkan kesadaran akan keragaman (plurality), kesetaraan (equality), kemanusiaan (humanity), keadilan (justice), dan nilai-nilai demokrasi (democration values) yang dibutuhkan setiap individu maupun kelompok masyarakat. Peserta didik diharapkan mampu menerima setiap perbedaan yang ada, memahami, dan menyikapinya secara arif. Minimal peserta didik dapat menyikapi perbedaan yang sederhana seperti yang sering mereka temui di bangku sekolah. Seperti kelas ekonomi, kelas sosial, perbeadaan warna kulit, bahasa atau bahkan bagi penyandang disabilitas yang kadang dimasukkan ke dalam kaum minoritas. Setelah itu, peserta didik akan dapat menjunjung tinggi hak-hak kemanusiaan. Memuliakan manusia sebagai ciptaan Tuhan yang paling sempurna. Menjadikan semuanya berkedudukan sama, sederajat, dan berlaku adil terhadap semua golongan.

Menurut Yaya dan Rusdiana ada tiga hal penting ${ }^{15}$ yang mendasari urgensi pendidikan multikultural. Pertama, masa depan memerlukan kreativitas, adalah masa depan yang hanya dapat dihadapi dengan kreativitas meskipun posisi keadaan sekarang memiliki peran penting untuk memicu kreativitas. Perubahan keadaan yang nonlinier ini tidak akan dapat diantisipasi dengan cara berpikir linier. Kedua, munculnya konflik sebagai konsekuensi dinamika kohesifitas sosial, maksudnya adalah bangsa seperti Indonesia dengan beragam kultur memiliki resistensi yang tinggi terhadap munculnya konflik sebagai konsekuensi dinamika kohesifitas sosial masyarakat. Maka pendidikan multikultural menjadi penting dan mendesak untuk diimplementasikan dalam praksis pendidikan di Indonesia. Fungsi pendidikan multikultural sebagai alternatif pemecahan konflik. Melalui pembelajaran yang berbasis multikultur, siswa diharapkan tidak tercerabut dari akar budayanya. Selain itu, pendidikan multikultural sangat relevan dipraktikkan dalam demokrasi seperti saat ini.

Ketiga, spektrum kultur masyarakat Indonesia merupakan tantangan, dalam artian spectrum kultur masyarakat Indonesia yang sangat beragam merupakan tantangan tersendiri bagi dunia pendidikan untuk mengolah ragam perbedan tersebut dapat dijadikan aset, bukan sumber perpecahan. Pada era globalisasi ini pendidikan multikultural memiliki tugas ganda, yaitu menyatukan bangsa yang terdiri atas berbagai macam budaya dan harus menyiapkan bangsa Indonesia untuk siap menghadapi arus budaya luar yang masuk kedalam negeri. Pendidikan multilkultural juga dapat dimanfaatkan untuk membina siswa agar tidak tercerabut dari akar budayanya. Hal ini disebabkan pertemuan antar budaya pada era globalisasi ini dapat menjadi ancaman serius bagi siswa. Siswa perlu diberi penyadaran akan pengetahuan yang beragam sehingga mereka memiliki kompetensi yang luas akan pengetahuan global, termasuk aspek kebudayaan.

15 Yaya dan Rusdiana, h. 255-256. 


\section{Implementasi Pendidikan Multikultural di SMA Nasional 3 Bahasa Putera Harapan Purwokerto (Pu Hua School)}

Dengan konsep "A Multicultural School”, sekolah ini menerima peserta didik dari berbagai macama latar belakang ras, etnis, budaya, dan agama. Hal ini dapat dilihat dari komposisi murid yang memiliki latar belakang agama sebagamana table berikut:

Tabel 1: Data Siswa SMA Nasional 3 Bahasa Putera Harapan Purwokerto Tahun 2019/2020

\begin{tabular}{cccccccc}
\hline Kelas & Islam & Kristen & Katholik & Hindu & Budha & Konghucu & Total \\
\hline X & 10 & 20 & 8 & - & 6 & 1 & 45 \\
XI & 8 & 19 & 20 & - & 4 & 4 & 55 \\
XII & 3 & 10 & 5 & - & - & - & 18 \\
Total & 21 & 49 & 33 & 0 & 10 & 5 & $\mathbf{1 1 8}$ \\
\hline
\end{tabular}

Dalam melaksanakan pendidikan multikultural SMA Nasional 3 Bahasa Putera Harapan Purwokerto tidak hanya terjadi pada proses pembelajaran di kelas saja namun juga terjadi di luar kelas seperti program-program sekolah yang berisi tentang kegiatan-kegiatan rutin maupun insidental yang menggambarkan pelaksanaan pendidikan multikultural secara langsung. Beberapa contoh kegiatan terkait pendidikan multikultural sebagaimana dalam tabel berikut ini.

Tabel 2: Program Kegiatan SMA Nasional 3 Bahasa Putera Harapan Purwokerto Tahum 2018/2019

\begin{tabular}{|c|c|c|}
\hline Kegiatan & Waktu & Keterangan \\
\hline Perayaan HUT RI & 16 Agustus 2018 & $\begin{array}{l}\text { Mengadakan perlombaan untuk murid dan } \\
\text { guru. }\end{array}$ \\
\hline Idhul Adha & 22 Agustus 2018 & $\begin{array}{l}\text { Penyembelihan dan pembagian hewan } \\
\text { kurban semua murid berpartisipasi } \\
\text { walaupun berbeda agama. }\end{array}$ \\
\hline Pu Hua Olimpic Games & 20 Septemebr 2018 & $\begin{array}{l}\text { Perlombaan berbagai macam olah raga } \\
\text { yang wajib diikuti seluruh siswa guna } \\
\text { melatih sportifitas dan solidaritas }\end{array}$ \\
\hline Perayaan Kue Bulan & 24 September 2018 & $\begin{array}{l}\text { Tradisi masyarakat Tiong Hoa namun } \\
\text { semua murid berpartisipasi mengikuti } \\
\text { kegiatan tersebut seperti lomba karaoke } \\
\text { Mandarin dan lomba menggunting. }\end{array}$ \\
\hline Perayaan Imlek Bersama & 16-17 Februari 2018 & $\begin{array}{l}\text { Diikuti seluruh siswa biasanya } \\
\text { menampilkan tarian Liong dan Barongsai } \\
\text { diiringi musik Tambur yang dimainkan } \\
\text { para siswa. }\end{array}$ \\
\hline English Guest Teacher & 4 September 2018 & $\begin{array}{l}\text { Sekolah mengundang warga negara asing } \\
\text { untuk menunjang kecakapan siswa dalam } \\
\text { berbahasa Inggris }\end{array}$ \\
\hline Bakti Sosial & Rutin & $\begin{array}{l}\text { Lokasi berubah-ubah seperti panti asuhan, } \\
\text { dsb }\end{array}$ \\
\hline
\end{tabular}




\begin{tabular}{|c|c|c|}
\hline Kegiatan & Waktu & Keterangan \\
\hline Berbagi Takjil & 14 Mei 2019 & $\begin{array}{l}\text { Dalam rangka berbagi kebaikan dan } \\
\text { toleransi yang di lakukan anak-anak OSIS } \\
\text { di bulan Ramadhan }\end{array}$ \\
\hline Doa Bersama & Rutin & $\begin{array}{l}\text { Dalam kegiatan ini siswa dan guru } \\
\text { melakukan doa bersama dengan tokoh } \\
\text { agama masing-masing untuk mengawali } \\
\text { kegiatan pembelajaran pada awal semester. }\end{array}$ \\
\hline Summer/Winter Camp & Rutin setiap tahun & $\begin{array}{l}\text { Kegiatan siswa mengunjungi negara China } \\
\text { untuk mempelajari tradisi, budaya dan } \\
\text { kunjungan situs bersejarah. }\end{array}$ \\
\hline Pemilihan Ketua OSIS & Rutin setiap tahun & $\begin{array}{l}\text { Di mana siswa melakukan proses } \\
\text { pemungutan suara secara demokrasi untuk } \\
\text { menentukan pemimpin OSIS }\end{array}$ \\
\hline
\end{tabular}

Sehubungan dengan paparan di atas, maka yang dimaksud dengan implementasi pendidikan multikultural yang diterapkan di SMA Nasional 3 Bahasa Putera Harapan Purwokerto (Pu Hua School) sesuai dengan konsep lima dimensi pendidikan multikultural yakni sebagai berikut:

\section{Integrasi Konten (Content Integration)}

Dalam hal penyusunan rancangan guru mengintegrasikan materi yang ada kaitannya dengan isu atau permasalahan multikultural dalam setiap bidang mata pelajaran sehingga siswa mampu memahami apa yang menjadi tujuan pembelajaran dalam hal ini seperti dalam kegiatan diskusi di kelas dengan suasana belajar siswa yang berbeda latar belakang agar mampu memfasilitasi semua pendapat dan pemikiran yang berbeda.

\section{Proses Penyusunan Pengetahuan (Construction Knowledge)}

Pengetahuan di sini yang dimaksud bukan hanya didapat di dalam pembelajaran kelas semata namun sekolah merancang program di luar kelas agar siswa menemukan makna dan nilai dari pendidikan multikultural itu sendiri seperti pada kegiatan perayaan hari besar umat beragama yang berbeda, di mana satu sama lain membantu menyukseskan acara tersebut. Seperti pada kegiatan perayaan Idul Adha di mana siswa muslim membuat acara penyembelihan dan pembagian daging kurban dengan melibatkan siswa beragama lain dalam hal kepanitiaan. Kemudian kegiatan bakti social yang berlangsung secara rutin diikuti semua siswa secara bergantian mengunjungi panti asuhan anak-anak muslim dan panti asuhan anak-anak non muslim. Kemudian pada saat Ramadhan siswa nonmuslim ikut serta dalam program pembagian takjil di jalan raya. Kegiatan lainnya seperti Winter/Summer Camp yaitu kunjungan ke Negeri China untuk mengenal lebih dalam budaya dan tradisi Tiong Hoa dan di sana mereka dapat langsung mempraktekan Bahasa Mandarin secara langsung. Sehingga mereka mampu menemukan pemahamannya sendiri melalui kegiatan secara nyata tersebut.

\section{Mengurangi Prasangka (Prejudice Reduction)}

Dalam rangka mengurangi prasangka maupun mencegah terjadinya konflik sekolah menanamkan pengertian bahwa setiap siswa tidak seharusnya menjadikan perbedaan yang 
ada sebagai suatu hal yang negatif tetapi justru menjadi hal yang positif seperti dengan kegiatan yang menuntut kekompakkan dan persatuan tim dalam perayaan HUT RI dan Pu Hua Olimpic Games di mana mereka berlomba berprestasi dan bekerjasma dalam tim yang sudah dibagi secara acak.

\section{Pedagogi Kesetaraan (Equity Paedagogy)}

Hal ini tentang bagaimana sikap guru dalam menjadi fasilitator dan pendidik mampu seimbang dan tidak ada perilaku membedakan siswa satu dengan lainnya mereka semua mendapat perlakuan sama dalam hak menerima ilmu pengetahuan, pendampingan belajar, serta dukungan meraih prestasi baik akademik maupun nonakademik. Contoh dalam mengikuti lomba pada kegiatan Bulan Bahasa di mana ada beberapa jenis lomba seperti story telling, pidato, puisi, drama dan lain-lain dalam Bahasa Indonesia, Bahasa Inggris, Bahasa Mandarin, dan Bahasa Jawa, siswa dipilih berdasarkan kompetensi dan skill yang menjadi ukuran, seperti lomba Bahasa mandarin tidak harus dari siswa keturunan Tiong Hoa bisa dari suku Jawa yang memang mahir dalam kompetensi tersebut.

\section{Budaya Sekolah dan Struktur Sekolah yang Memberdayakan (Empowering School Culture and Social Culture)}

Bukan hanya keadaan siswa yang berbeda latar belakang suku, agama, ras, budaya, dan Bahasa namun juga demikian dengan guru dan karyawan di SMA Nasional 3 Bahasa Putera Harapan Purwokerto (Pu Hua School). Mereka dapat bersinergi bersama antara siswa, guru, dan karyawan dalam satu lingkungan. Sinergitas ini dapat dibuktikan dalam beberapa agenda kegiatan sekolah yang melibatkan seluruh elemen warga sekolah seperti contoh kegiatan perayaan HUT RI, Pu Hua Olimpic Games, Perayaan Imlek Bersama, Perayaan Kue Bulan, dan Do'a bersama awal pembelajaran.

Kemudian dalam kaitannya dengan penerapan nilai-nilai pendidikan multikultural pada setiap kegiatan yang disusun dan dilaksanakan. Pertama: nilai demokrasi, dalam menerapkan nilai ini sekolah memberikan porsi yang sama dalam kebebasan berpendapat dan menyampaikan ide serta memilih apa yang menjadi minat. Di dalam kelas siswa berdiskusi satu dengan lainnya sesuai dengan tema pembelajaran dan semua mempunyai hak yang sama dalam menyampaikan dan menerima informasi ilmu pengetahuan tidak ada siswa paling mendominasi dan menghegemoni. Kegiatan di luar kelas seperti dalam pemilihan ketua OSIS yang dipilih secara langsung siswa yang dicalonkan berdasarkan kualifikasi dan potensinya entah itu dari suku apa dan beragama apa, mereka dipilih karena figure, popularitas, serta visi dan misi yang diusungnya.

Kedua: Nilai Humanisme, dalam penerapan nilai ini sekolah mengakomodasi segala apa yang dibutuhkan siswa secara optimal. Hal ini terbukti dengan fasilitas sumber belajar yang memadai, kemudian membiarkan siswa memilih ekstrakurikuler untuk mengembangkan bakat siswa yang diminatinya. Contoh program lain terkait pengembangan Bahasa, sekolah membuat program Guest Teacher di mana pihak sekolah mengundang warga negara asing untung menguji dan mengembangkan kemampuan berbahasa asing siswa. Jadi sekolah secara baik dalam memfasilitasi apa yang menjadi kebutuhan siswa.

Ketiga: Nilai Pluralisme, penerapan nilai ini secara nyata terbukti pada keseharian siswa di sekolah di mana mereka saling mengingatkan satu sama lain dalam hal rutinitas 
ibadah. Secara rutin sekolah ini menyelenggarakan doa bersama awal pembelajaran di mana siswa berdoa dengan para pemuka agamanya masing-masing di ruangan yang sudah disiapkan. Selain itu sikap toleransi terbentuk dan tertuang saat kegiatan perayaan hari besar keagamaan dan kegiatan berkaitan dengan budaya seperti permainan Barongsai, Liong, Tambur, yang bukan hanya etnis Tiong Hoa saja yang dapat melakukan permainan tersebut tetapi yang lainpun bisa. Dalam memperingati Sumpah Pemuda sekolah mengadakan acara tabur bunga mengunjungi taman makam pahlawan, di mana kegiatan ini diharapkan menanamkan jiwa nasionalisme siswa bahwa persatuan Indonesia itu tercipta dari perjuangan dan pengorbanan para pahlawan tanpa memandang darimana asal mereka, apa suku, agama, dan budayanya. Sehingga jiwa pluralisme siswa akan dapat tertanam dengan baik untuk dapat hidup berdampingan, menerima dan mengakui perbedaan yang ada sematamata untuk mengukuhkan persatuan Negara Kesatuan Republik Indonesia.

\section{E. Simpulan}

Pada hakikatnya perbedaan merupakan sunatullah yang niscaya, hal itu merupakan rahmat yang harus disyukuri manusia. Dengan mengenal dan memahami perbedaan yang ada membuat manusia dapat hidup berdampingan dengan baik satu sama lainnya. Pendidikan Multikultural merupakan konsep pendidikan yang mampu menjawab permasalahan yang sering terjadi di Indonesia, negara dengan keragaman masyarakatnya yang luar biasa. Dengan menanamkan pendidikan multikultural secara terus menerus diharapkan mampu mencegah konflik dan ketegangan yang terjadi di masyarakat yang masih sering terjadi karena kesalahpahaman dan provokasi dari pihak yang berkepentingan dan berniat memecah belah bangsa Indonesia.

Pendidikan Multikultural dapat diterapkan seharusnya diterapkan sejak dari dini, dan keluarga sangat berperan penting dalam menanamkan nilai-nilai pendidikan multikultural tidak hanya di sekolah namun juga di rumah. Hal ini penting mengingat kondisi masyarakat Indonesia yang majemuk dengan segala maca keragaman dan perbedaan yang ada sehingga rawan terjadi konflik bukan hanya karena timbul sikap fanatik agama atau sikap primordialisme lebih dari itu berpotensi mendominasi kelompok satu terhadap kelompok lainnya. Untuk itu pendidikan multikultural menjadi tepat untuk diterapkan terutama di sekolah di mana anak akan berjumpa secara langsung orang dan lingkungan yang berbeda untuk memberinya pengalaman hidup tetap bersama di dalam perbedaan. 


\section{Daftar Pustaka}

al-Quran al-Karim, Departemen Agama RI, al Qur'an dan Terjemahannya: 1-30. (Jakarta: PT. Kumudasmoro Grafindo Semarang, 1994)

Banks, James.A. An Introduction to Multicultural Education (Boston- London: Allyn and Bacon Press, 2002)

H.A.R. Tilaar, Jimmy dan Lody, Pedagogik Kritis (Jakarta: Rineka Cipta, 2011)

Herdiansyah, Haris. Metodologi Penelitian Kualitatif untuk Ilmu-ilmu Sosial (Jakarta: Salemba Humanika, 2014)

Kompas, Penelitian: Kasus Intoleransi Masih Sering Terjadi di Jateng Selama 2017 dalam https://amp.kompas.com/regional/read/2018/01/09/13593181/penelitian-kasusintoleransi-di-jateng-selama-2017

Mahfud, Choirul. Pendidikan Multikultural (Yogyakarta: Pustaka Pelajar, 2008)

Maryam, Kurniawati. Pendidikan Kristiani Multikultural (Tangerang: Bamboo Bridge Press, 2014)

Rusdiana dan Yaya. Pendidikan Multikultural (Bandung: Pustaka Setia, 2015)

Wijaya, David. Pendidikan Budaya dan Karakter Bangsa Untuk Sekolah dan Perguruan Tinggi (Jakarta: Mitra Wacana Media, 2017)

Zamroni, The Implementation of Multicultural Education. a Reader (Yogyakarta: Graduate Program the State University of Yogyakarta: Tiara Wacana Yogya, 2010)

Zuriah, Nurul, "Model Pengembangan Pendidikan Pewarganegaraan Multikultural Berbasis Kearifan Lokal dalam Fenomena Sosial Pasca Reformasi di Perguruan Tinggi”, Jurnal Penelitian UPI, 12.2 (2011) 